\title{
Kinetics of immune reconstitution and immune complications after cell and organ transplantation
}

\author{
Usha Kellampalli, Hesham Mohei and Irina Vlasova-St. Louis* \\ Department of Medicine, University of Minnesota, Minneapolis, USA
}

\begin{abstract}
In this review, we have focused on immune restoration after allogeneic hematopoietic stem cell transplantation (allo-HSCT) and solid organ transplantations (SOT). We discuss the kinetics of cytokine secretion during immune reconstitution phases that play a unique role in the connection between innate and adaptive immunity, therefore essential in normal and pathological immune reconstitution. We overview the importance of T cell immunity for antigen-specific immune reconstitution and the production of cytokines. We briefly touch upon a graft versus host disease and other immunopathology that accompany poor immune restoration after transplantation and discuss therapeutic interventions.
\end{abstract}

\begin{abstract}
Abbreviation: NKG2D: Lectin-like type 2 transmembrane receptor encoded by gene Klrk1 (killer cell lectin-like receptor subfamily member 1; IRIS: Immune Reconstitution Inflammatory Syndrome

\section{Introduction}

Recent advances in solid organ and allogeneic hematopoietic stem cell transplantations (allo-HSCT) in the field of oncology have been attributed to stringent HLA matching between donors and recipients and impressive ranges of immunosuppressive therapy. However, new challenges have emerged, such as immune restoration disorders, which are represented by the unique symptomocomplexes of maladaptive recovery of the immune system. Patients eligible for transplant undergo high doses of chemo- or- radiation therapy, before transplantation, and prolonged iatrogenic immunosuppression afterward. Significant morbidity and mortality have reported in these patients due to viral infections, transplant rejection, graft versus host disease, or malignant disease relapse (Figure 1) [1]. During immune reconstitution, adequate interactions between innate and adaptive immunity are key players in maintaining the capacity to generate $\mathrm{T}$ cell populations that are able to control pathogens and to preserve peripheral tolerance.
\end{abstract}

Interaction between innate and adaptive immunity and immune reconstitution disorders

The fundamentals of immune system activation are complexed, they appear to begin with activation of innate phagocytic leukocytes (macrophages) by processed antigens. Activated macrophages secrete cytokines which are essential for communication between lymphocytes and macrophages, and play a unique role in macrophage M0 to M1/ M2 polarization [2]. M1 type macrophages express CD86 and secrete inflammatory mediators like tumor necrosis factor-alpha (TNFA), IL1B, IL6, IL8, IL12, and IL23 [3,4]. M1 type is predominantly developed during acute infection when M0 macrophages are stimulated by cytokine interferon-gamma (IFNG), along with pathogen-associated molecular pattern molecules (PAMPs) [5]. Activated M1 macrophages concentrate to the site of infection and induce inflammation via nitric oxide (NO), reactive oxygen intermediates (ROI), and other damaging molecules. Subsequently, M1 polarizes into M2 type by IL4, IL10, IL13, and transforming growth factor-beta (TGFB), secreted by T cells. These macrophages phagocytose cellular debris to resolve inflammation and to facilitate wound healing [6,7]. M2 macrophages abundantly express mannose receptor, dectin-1, CD163, CD209, scavenger receptor A and B1, CCR2, CXCR1, and CXCR2. Additionally, M2 type exhibits different metabolic profiles: high production of ornithine and polyamines through the arginase pathway [8].

The proper switch between the M1/M2 phenotypes is important to the resolution of inflammation. It is controlled by T-helper (Th1/Th2) cells, effector T cells, and T-regulatory (Treg) cells [8-11]. However, in the settings of immunodeficiency, inappropriate macrophage polarization drives immune reconstitution pathology [12]. In the absence of IFNG signaling, macrophage activation by interferon alfa (IFN type II, IFNA) is likely to take over in T-cell- deficient patients with compromised IFNG responses [13]. IFNA displays protective anti-inflammatory functions via direct inhibition of pro-inflammatory cytokines, inductions of cytokine antagonists, or re-directing the signaling through negative feedback loops [14]. Thus, in the immunocompromised host, adjunct IFNG (IFN type II) and IFNA (IFN type I) treatments may allow the switch of the M1 polarization proinflammatory arm to the $\mathrm{M} 2$ polarization arm in order to control the inflammatory symptoms during post-transplantation immune reconstitution disorders.

Several animal model studies revealed that the induction of longterm allograft survival by the blockade of the CD28 and CD40 ligand $\mathrm{T}$ cell co-stimulation pathways is dependent on IFNG expression [1517]. Through this mechanism IFNG limits expansion of activated $T$ cells and facilitates long-term acceptance of transplanted organs. The pitfall, however, is that the excess of IFNG can promote vasculopathy

${ }^{*}$ Correspondence to: Irina Vlasova-St. Louis, Department of Medicine, University of Minnesota, Minneapolis, MN, USA, E-mail: irinastl@umn.edu

Key words: immune reconstitution disorders; cytokines; interferons; allo-HSCT; T cells; NK cells; solid organ transplantation; IRIS

Received: June 08, 2020; Accepted: June 27, 2020; Published: June 29, 2020 


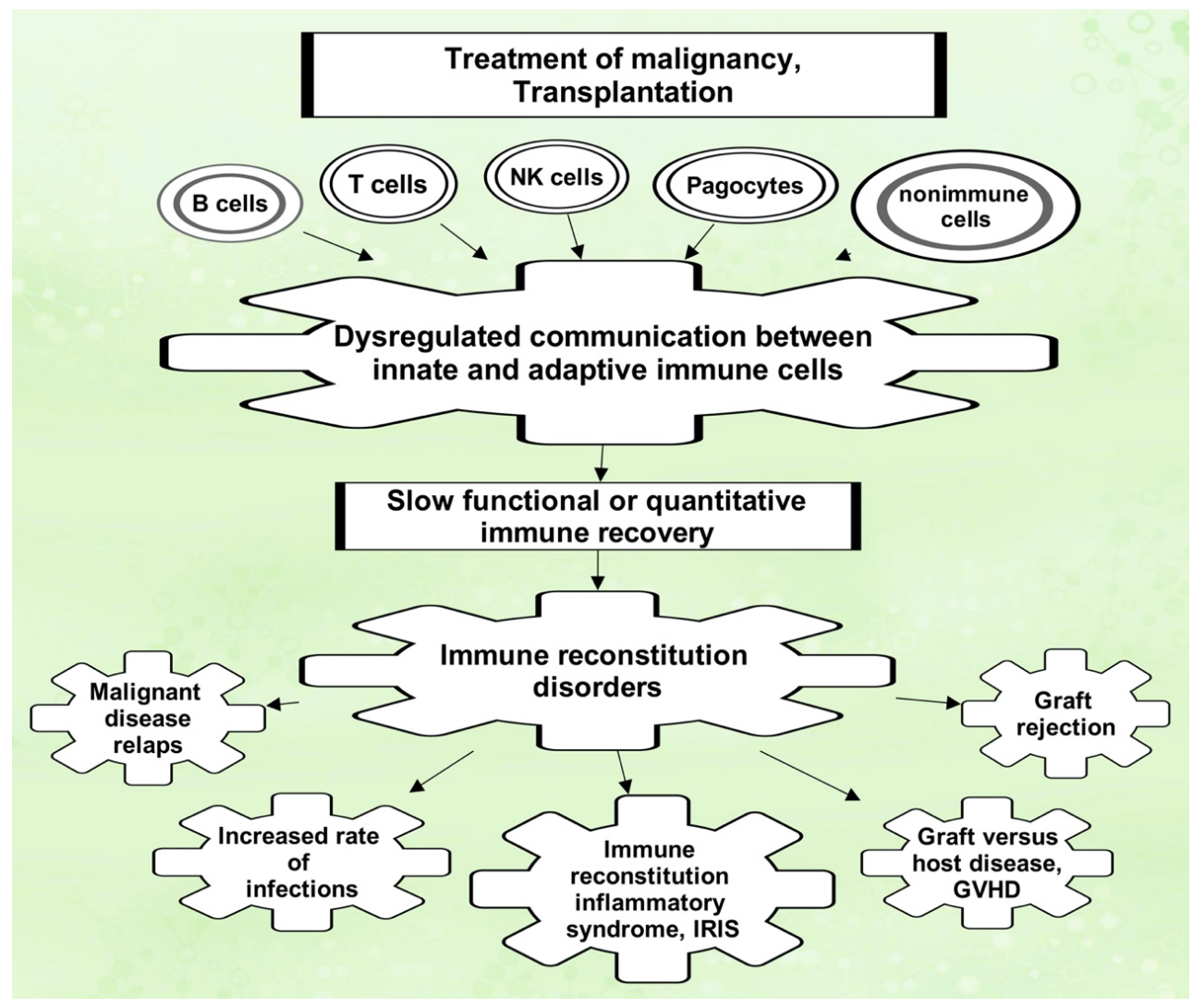

Figure 1. Immune complications after cell and organ transplantation

in solid organ recipients through immune cell activation and vascular remodeling [18,19]. Chronic rejection presents in the allograft vasculature as an immune-mediated, progressive vascular occlusion that results in ischemia and subsequent graft death [20]. Interleukin (IL33) is released from damaged or dying cells, triggers Th2-biased immune cell activation regulatory $\mathrm{T}$ cell and $\mathrm{M} 2$ macrophage expansion at the sites of graft rejection. By promoting $\mathrm{T}$ helper type 2 immunity, IL33 counterbalances IFNG-dominated Th type 1 immunity. It has been demonstrated that injections of IL33 reduce the formation of atherosclerotic plaques and vasculopathy, via driving the switch of a Th1 to Th2 in apolipoprotein E deficient animals [21], which suggests potential applicability of IL33 as biologics, in treating solid-organ recipients experiencing chronic allograph rejection. However, due to activation of NK cell-mediated hyper-cytotoxicity through CD95, granzymes, and perforins, IL33 usage is limited in the context of contact-dependent cardiac allograft rejection driven by abnormal IFNG production [22].

Natural killer (NK) cells are generally considered to be components of innate immune defense because they lack antigen-specific cell surface receptors [23]. NK cells have been recognized as major producers of cytokines such as IFNG in many physiological and pathological conditions [24]. NK cells also produce an array of other cytokines, both pro-inflammatory and immunosuppressive, such as TNFA and IL10, respectively. Also, they secrete growth factors such as GMCSF, GCSF, and IL3. In addition, NK cells are able to secrete chemokines, including CCL2, CCL3, CCL4, CCL5, and CXCL8 [25]. Recently, NK cells have been discovered to possess functions of an adaptive immune response. Immunological memory is a hallmark of adaptive immunity [26]. In vitro-activated NK cells (with cytokines IL12, IL15, IL18) and subsequently adoptively transferred into naïve mouse recipients have an enhanced ability to produce IFNG upon re-stimulation. These findings suggest that once activated mature NK cells may acquire stable, heritable properties that influence their behavior during subsequent infections [27]. Thus, NK cells appear to remember their past encounter with the antigens, which may be utilized as a future therapeutic strategy to combat post-transplantation immune reconstitution pathology $[28,29]$.

\section{Kinetics of innate and adaptive immune reconstitution in allo-HSCT recipients}

Stem cell transplantation has become a lifesaving treatment for patients with immuno-hematological malignancies. For patients who undergo allo-HSCT, immune recovery is often accompanied by a high risk of infection-associated morbidity and mortality [30-38]. AlloHSCT from HLA-matched sibling donors (MSD) generally provides the best clinical outcomes [39]. Banked umbilical cord blood (UCB) is a viable alternative for patients who don't have MSD [40].

To evaluate quantitative and qualitative immune recoveries several studies have been conducted [35,41-44]. In UCB recipients, slower T cell subset recovery with lower numbers of $\mathrm{CD} 3+\mathrm{CD} 8+$ (naïve and effector), $\mathrm{CD} 3+\mathrm{CD} 4+$ (naive and memory), and regulatory $\mathrm{T}$ cells were observed, than in MSD recipients, from day 60 to 1 year of observation [45]. Studies showed that sufficient IFNG production by CD4+ and CD8+ $\mathrm{T}$ cells toward viral antigens protects the recipients from reactivation of many latent viral diseases, particularly cytomegalovirus, CMV $[46,47]$. However, the rate of recovery and maturation of NK cells, and NK-driven IFNG production, did not significantly influence the occurrence of viral infections after allo-HSCT [48]. Higher frequency of viral infections and delayed immune $\mathrm{T}$ cell reconstitution was observed in UCB recipients [40,49-52]. It is hypothesized that 
adaptive and innate immune cells synergize their effort to control latent infections in UCB stem cell transplant patients. Several studies showed rapid quantitative recovery of NK cells after transplantation, however, in the absence of thymic function and incomplete recovery of $\mathrm{T}$ cells, NK cells alone do not sufficiently function to combat infections unless combined with gene-modified virus-specific adaptively transferred T lymphocytes $[53,54]$. The excessive expansion of natural killer cells in in vitro assays has previously been reported to inhibit $\mathrm{T}$ cells' proliferation via p21 overexpression, and NKG2D-expressing NK cells exhibit cytotoxicity towards T helper cells, specifically Th17 cells [55]. However, we still need to understand in vivo communication between NK-, T-, and antigen-presenting cells during immune reconstitution in recipients who undergo various cellular treatment regimens [56-59].

Several studies showed that the incomplete ablation of NK cells in the graft resulted in the improvement of recipients' outcomes, but donor-recipient KIR ligand matching might be an even more efficient strategy for NK cell-mediated protection against CMV reactivation $[29,60]$. On the other hand, the expansion of Tregs inhibits proinflammatory responses in immune cells from the adaptive and innate compartments including NK cells and antigen-presenting cells (APCs) [61]. This is why in vitro expanded Tregs might be an attractive approach to achieve normal kinetics of immune reconstitution after transplantation [62-64]. Both options need to be further explored.

\section{Treatment approaches for improvement of allogeneic HSCT immune recovery}

It is very important for immune reconstitution that the grafts yield a sufficient amount of hematopoietic stem cells (CD34+ HSC). Mobilization of donors with granulocyte-colony stimulating factor (G-CSF) is the standard procedure for peripheral blood stem cell grafts in allo-HSCT. The addition of subcutaneous injection of drug plerixafor improves CD34+ HSC recovery from the graft, without altering the $\mathrm{T}$ and NK cell recovery, including Tregs cells, with anticipation to improve long-term transplant outcomes [65].

Post-transplantation, the adoptive transfer of $\mathrm{T}$ cells targeting the viral antigens during immune reconstitution can treat infections [66]. Adoptively transferred Epstein Barr virus (EBV) specific CD4+ and $\mathrm{CD} 8+\mathrm{T}$ lymphocytes from the donor can reconstitute the patient's immune responses against EBV [54]. After allo-HSCT, cytomegalovirus (CMV)-specific $\mathrm{T}$ cells are used for the successful treatment of refractory CMV infections [67,68], and adenovirus-specific $\mathrm{T}$ cells from a donor are used for the treatment of patients with adenovirus infections [69]. Invasive fungal infections (especially aspergillosis) are another example of therapeutic applications of fungal specific $\mathrm{T}$ cell transfers [70]. Treatment with aspergillus-specific $\mathrm{T}$ cells has shown suppression of antigenemia and the prevention of invasive aspergillosis in many patients [71]. Hence, the adaptive cellular immune therapy has shown high efficacy in restoring the anti-infectious $\mathrm{T}$ cell immunity after allo-HSCT [72].

Many clinical studies test cytokine agonist-receptor complexes. Several studies have shown the benefit of IL15 analogs to restore immune homeostasis in transplant recipients. After allo-HSCT, immune activation was enhanced within 2 months with IL15/ IL15R complexes and didn't increase the rate of adverse events [73]. Exogenous administration of IL7 has shown to boost antigen-specific $\mathrm{T}$ cell responses to viral infections [74]. A phase 1 clinical trial of recombinant human IL7 (hIL7) showed that CD3+, CD4+, and CD8+ counts are increased in hIL7-treated allo-HSCT recipients [75]. Hence,
hIL7 carries a positive perspective for new treatment approaches to immune reconstitution disorders [59].

\section{Kinetics of immune reconstitution and immune complications after solid organ transplantation}

In solid organ transplantation (SOT), the proinflammatory responses triggered by the gradual decrease of immunosuppressive agents, but the continuation of antimicrobial and antiviral therapies are believed to be behind the development of post-transplant immune reconstitution pathology [65]. This pathology is presented in three forms; allograft rejection, graft versus host disease (GVHD), and immune reconstitution inflammatory syndrome (IRIS).

Th1 and Th17 cells are the primary mediators of allograft rejection. On the other hand, Tregs and Th2 cells promote graft tolerance [7679]. The immunosuppressive regimens are the gold standard in transplant recipients to induce tolerance by downregulating Th1, Th17 cells, and upregulating Th2 cells, with or without Tregs expansion [80]. Combined immunosuppression with calcineurin inhibitors, mycophenolate mofetil, and steroids has emerged as a risk factor for cryptococcus (C.) neoformans-induced IRIS in adult SOT recipients. Calcineurin inhibitors like tacrolimus and cyclosporine A suppress Th1 cells and boost Th2 cell activity [81-83]. Also, they inhibit proliferation of Tregs (CD4+CD25+FoxP3+ cells) by blocking IL2 production $[84,85]$. By blocking IL2, immunosuppression causes a qualitative $\mathrm{CD} 4+$ deficiency, resembling the quantitative defect that characterizes HIV infection. Thus, the withdrawal of these anti-IL2 agents in SOT recipients could theoretically direct the balance toward pro-inflammatory responses of memory $\mathrm{T}$ cells, resembling the effect of CD4+ count comeback in HIV patients post ART. Moreover, calcineurin inhibitors and rapamycin inhibit Th17 cell generation [8688]. Corticosteroids suppress Th1 cells and marginally promote Th2 cells and Tregs $[89,90]$.

In the adult SOT population, immune reconstitution inflammatory syndrome (IRIS) has been reported as a paradoxical clinical deterioration following the initiation of antifungal regimens to combat opportunistic mycoses with a high incidence of graft failure in renal transplant recipients [91-95]. Typically, the patient shows an initial improvement, followed shortly by a deterioration similar to what was first described in HIV patients post ART [96,97]. Clinical findings of IRIS in SOT recipients are similar to those in patients with HIV with both local and systemic manifestations: painful lymphadenitis, high fever, central nervous system manifestations, and soft tissue infections $[96,98,99]$. In the adult SOT population, the C. neoformans is the pathogen most commonly associated with IRIS $[91,96]$. Other reported pathogens include CMV and Mycobacterium tuberculosis [92,93].

The most significant determinant that impacts post-transplant quality of life is graft versus host disease (GVHD). In survivors of solid organ transplant, GVHD is a major cause of long-term morbidity and mortality. Contradictory evidence revealed that IL33 can either constrain or promote type 1 immune responses during GVHD [100102]. The timing of IL33 administration and/or release may represent the crossroad that identifies the direction of immune response effectuated. IL33 infusion of recipients before the myeloablative conditioning regimens led to the expansion of populations of myeloablation resistant host Treg cells [103]. These IL33-expanded Treg cells constrained donor effector T cells to GVHD-targeted tissues and obviated GVHD [103]. When administered after allo-HSCT, IL33 inversely associated with exacerbation of acute GVHD-related lethality in mice [104]. Thus, the timing of treatment with IL33 may be beneficial for the outcomes if 
the alloimmune response is driven away from the typical Th1 response towards a Th2 type immune response.

The prevention of chronic rejection of the allograft is still a preeminent challenge in SOT. Experimental and clinical data suggested a significant role for allospecific immune responses, particularly IFNG producing $\mathrm{T}$ cells in chronic rejection of the allograft [105-107]. The redirection of Th1 response towards Th2 immunity has been hypothesized to be a promoter for allograft survival and tolerance with less atherosclerosis $[18,108,109]$.

Although IL33 treatment may be promising in chronic allograft rejection, it has been suggested that Th2 cytokines can promote acute graft dysfunction as both Th1 type and Th2 type cytokines are expressed in acute phase rejection [109-111]. Additionally, IL5 secreted by Th2 and eosinophils have been specifically described as potent mediators of acute graft rejection [112].

\section{Summary}

Adequate immune reconstitution after allo-HSCT or solid organ transplantation is the most important determinant for survival, as most life-threatening complications (e.g. viral infections, IRIS or GVHD) are associated with delayed immune function restoration and poor outcomes. The development of novel biotherapeutics and repurposing of existing drugs and biologics, with potentially more selective approaches for achieving the control over viral reactivations and durable graft tolerance, may in the future reduce the need for iatrogenic immune suppression post-transplantation.

\section{References}

1. Norkin M, Wingard JR (2017) Recent advances in hematopoietic stem cell transplantation. F1000Res 6: 870. [Crossref]

2. Wang N, Liang H, Zen K (2014) Molecular mechanisms that influence the macrophage m1-m2 polarization balance. Front Immunol 5: 614. [Crossref]

3. Lee S, Huen S, Nishio H, Nishio S, Lee HK, et al. (2011) Distinct macrophage phenotypes contribute to kidney injury and repair. J Am Soc Nephrol 22: 317-326. [Crossref]

4. Williams H, Cassorla G, Pertsoulis N, Patel V, Vicaretti M, et al. (2017) Human classical monocytes display unbalanced M1/M2 phenotype with increased atherosclerotic risk and presence of disease. Int Angiol 36: 145-155. [Crossref]

5. Vlasova-St.Louis I, Bohjanen PR (2016) Post-transcriptional Regulation of Cytokine Signaling During Inflammatory Responses. Vol. chapter 3. Switzerland: In: Goldstrohm AC, Menon KMJ (Eds.), Post-transcriptional Mechanisms in Endocrine Regulation, Springer, Switzerland: 55-70 (A.C. Goldstrohm KMJM, ed).

6. Wolfs IM, Donners MM, de Winther MP (2011) Differentiation factors and cytokines in the atherosclerotic plaque micro-environment as a trigger for macrophage polarisation. Thromb Haemost 106: 763-771. [Crossref]

7. Cao Q, Harris DC, Wang Y (2015) Macrophages in kidney injury, inflammation, and fibrosis. Physiology (Bethesda) 30: 183-194. [Crossref]

8. Chistiakov DA, Myasoedova VA, Revin VV, Orekhov AN, Bobryshev YV (2018) The impact of interferon-regulatory factors to macrophage differentiation and polarization into M1 and M2. Immunobiology 223: 101-111. [Crossref]

9. McNab FW, Ewbank J, Howes A, Moreira-Teixeira L, Martirosyan A, et al. (2014) Type I IFN induces IL-10 production in an IL-27-independent manner and blocks responsiveness to IFN-gamma for production of IL-12 and bacterial killing in Mycobacterium tuberculosis-infected macrophages. J Immunol 93: 3600-3612. [Crossref]

10. Slavcev A, Rybakova K, Svobodova E, Slatinska J, Honsova E, et al. (2015) Pretransplant donor-specific Interferon-gamma-producing cells and acute rejection of the kidney allograft. Transpl Immunol 33: 63-68.

11. Boyette LB, Macedo C, Hadi K, Elinoff BD, Walters JT, et al. (2017) Phenotype, function, and differentiation potential of human monocyte subsets. PLoS One 12: e0176460. [Crossref]
12. Vlasova-St Louis I, Bohjanen PR (2017) Post-transcriptional regulation of cytokine and growth factor signaling in cancer. Cytokine Growth Factor Rev 33: 83-93. [Crossref]

13. Mohei H, Kellampalli U, Vlasova SL (2019) Immune Reconstitution Disorders: Spotlight on Interferons. Int J Biomed Investig 2: 1-21. [https://doi.org/10.31531/2581-4745.1000119]

14. Moreira-Teixeira L, Mayer-Barber K, Sher A, O'Garra A (2018) Type I interferons in tuberculosis: Foe and occasionally friend. J Exp Med 215: 1273-1285. [Crossref]

15. Liu R, Merola J, Manes TD, Qin L, Tietjen GT, et al. (2018) Interferon- $\gamma$ converts human microvascular pericytes into negative regulators of alloimmunity through induction of indoleamine 2,3-dioxygenase 1. JCI Insight 3: e97881. [Crossref]

16. Konieczny BT, Dai Z, Elwood ET, Saleem S, Linsley PS, et al. (1998) IFN-gamma is critical for long-term allograft survival induced by blocking the CD28 and CD40 ligand T cell costimulation pathways. J Immunol 160: 2059-2064. [Crossref]

17. Refaeli Y, Van Parijs L, Alexander SI, Abbas AK (2002) Interferon gamma is required for activation-induced death of T lymphocytes. J Exp Med 196: 999-1005. [Crossref]

18. Hansson GK, Libby P (2006) The immune response in atherosclerosis: a double-edged sword. Nat Rev Immunol 6: 508-519. [Crossref]

19. Sikorski K, Czerwoniec A, Bujnicki JM, Wesoly J, Bluyssen HA (2011) STAT1 as a novel therapeutical target in pro-atherogenic signal integration of IFN $\gamma$, TLR4 and IL-6 in vascular disease. Cytokine Growth Factor Rev 22: 211-9. [Crossref]

20. Tellides G, Pober JS (2007) Interferon-gamma axis in graft arteriosclerosis. Circ Res 100: 622-632. [Crossref]

21. Miller AM, Xu D, Asquith DL, Denby L, et al. (2008) IL-33 reduces the development of atherosclerosis. J Exp Med 205: 339-346. [Crossref]

22. Lin CM, Plenter RJ, Coulombe M, Gill RG (2016) Interferon Gamma and Contactdependent Cytotoxicity Are Each Rate Limiting for Natural Killer Cell-Mediated Antibody-dependent Chronic Rejection. Am J Transplant 16: 3121-3130. [Crossref]

23. Zitti B, Bryceson YT (2018) Natural killer cells in inflammation and autoimmunity Cytokine Growth Factor Rev 42: 37-46. [Crossref]

24. Zhang S, Saha B, Kodys K, Szabo G (2013) IFN-gamma production by human natural killer cells in response to $\mathrm{HCV}$-infected hepatoma cells is dependent on accessory cells. J Hepatol 59: 442-449. [Crossref]

25. Walzer T, Dalod M, Robbins SH, Zitvogel L, Vivier E (2005) Natural-killer cells and dendritic cells: "l'union fait la force". Blood 106: 2252-2258. [Crossref]

26. Vivier E, Raulet DH, Moretta A, Caligiuri MA, Zitvogel L, et al. (2011) Innate or adaptive immunity? The example of natural killer cells. Science 331: 44-49. [Crossref]

27. Cooper MA, Elliott JM, Keyel PA, Yang L, Carrero JA, et al. (2009) Cytokine-induced memory-like natural killer cells. Proc Natl Acad Sci U S A 106: 1915-1919. [Crossref]

28. Bozzano F, Marras F, De Maria A (2017) Natural Killer Cell Development and Maturation Revisited: Possible Implications of a Novel Distinct Lin. Front Immunol 8: 268. [Crossref]

29. Zhao XY, Luo XY, Yu XX, et al. (2017) Recipient-donor KIR ligand matching prevents CMV reactivation post-haploidentical T cell-replete transplantation. $\mathrm{Br} J$ Haematol 177: 766-781. [Crossref]

30. Jacobson CA, Turki AT, McDonough SM, Stevenson KE, Kim HT, et al. (2012) Immune reconstitution after double umbilical cord blood stem cell transplantation: comparison with unrelated peripheral blood stem cell transplantation. Biol Blood Marrow Transplant 18: 565-574. [Crossref]

31. Komanduri KV, St John LS, de Lima M, McMannis J, Rosinski S, et al. (2007) Delayed immune reconstitution after cord blood transplantation is characterized by impaired thymopoiesis and late memory T-cell skewing. Blood 110: 4543-4551. [Crossref]

32. Majhail NS, Rizzo JD, Lee SJ, Aljurf M, Atsuta Y, et al. (2012) Recommended screening and preventive practices for long-term survivors after hematopoietic cell transplantation. Biol Blood Marrow Transplant 18: 348-371. [Crossref]

33. Parody R, Martino R, Rovira M, Vazquez L, Vázquez MJ, et al. (2006) Severe infections after unrelated donor allogeneic hematopoietic stem cell transplantation in adults: comparison of cord blood transplantation with peripheral blood and bone marrow transplantation. Biol Blood Marrow Transplant 12: 734-748. [Crossref]

34. Ruggeri A, Peffault de Latour R, Carmagnat M, Clave E, Douay C, et al. (2011) Outcomes, infections, and immune reconstitution after double cord blood transplantation in patients with high-risk hematological diseases. Transpl Infect Dis 13: 456-465. [Crossref]

35. Saliba RM, Rezvani K, Leen A, Jorgensen J, Shah N, et al. (2015) General and VirusSpecific Immune Cell Reconstitution after Double Cord Blood Transplantation. Biol Blood Marrow Transplant 21: 1284-1290. [Crossref] 
36. Sauter C, Abboud M, Jia X, Heller G, Gonzales AM, et al. (2011) Serious infection risk and immune recovery after double-unit cord blood transplantation without antithymocyte globulin. Biol Blood Marrow Transplant 17: 1460-1471. [Crossref]

37. Somers JA, Brand A, van Hensbergen Y, Mulder A, Oudshoorn M, et al. (2013) Double umbilical cord blood transplantation: a study of early engraftment kinetics in leukocyte subsets using HLA-specific monoclonal antibodies. Biol Blood Marrow Transplant 19: 266-73. [Crossref]

38. Young JH, Logan BR, Wu J, Wingard JR, Weisdorf DJ, et al. (2016) Infections after Transplantation of Bone Marrow or Peripheral Blood Stem Cells from Unrelated Donors. Biol Blood Marrow Transplant 22: 359-370. [Crossref]

39. Majhail NS, Weisdorf DJ, Wagner JE, Defor TE, Brunstein CG, et al. (2006) Comparable results of umbilical cord blood and HLA-matched sibling donor hematopoietic stem cell transplantation after reduced-intensity preparative regimen for advanced Hodgkin lymphoma. Blood 107: 3804-3807. [Crossref]

40. Brunstein CG, Barker JN, Weisdorf DJ, DeFor TE, Miller JS, et al. (2007) Umbilical cord blood transplantation after nonmyeloablative conditioning: impact on transplantation outcomes in 110 adults with hematologic disease. Blood 110: 3064 3070. [Crossref]

41. Pei XY, Zhao XY, Chang YJ, Liu J, Xu LP, et al. (2017) Cytomegalovirus-Specific T-Cell Transfer for Refractory Cytomegalovirus Infection After Haploidentical Stem Cell Transplantation: The Quantitative and Qualitative Immune Recovery for Cytomegalovirus. J Infect Dis 216: 945-956. [Crossref]

42. Yew PY, Alachkar H, Yamaguchi R, Kiyotani K, Fang H, et al. (2015) Quantitative characterization of T-cell repertoire in allogeneic hematopoietic stem cell transplant recipients. Bone Marrow Transplant 50: 1227-1234. [Crossref]

43. Kanda J, Chiou LW, Szabolcs P, Sempowski GD, Rizzieri DA, et al. (2012) Immune recovery in adult patients after myeloablative dual umbilical cord blood, matched sibling, and matched unrelated donor hematopoietic cell transplantation. Biol Blood Marrow Transplant 18: 1664-1676.e1. [Crossref]

44. Schulenburg A, Fischer M, Kalhs P, Mitterbauer M, Rabitsch W, et al. (2005) Immune recovery after conventional and non-myeloablative allogeneic stem cell transplantation. Leuk Lymphoma 46: 1755-1760. [Crossref]

45. Bejanyan N, Brunstein CG, Cao Q, Lazaryan A, Luo X, et al. (2018) Delayed immune reconstitution after allogeneic transplantation increases the risks of mortality and chronic GVHD. Blood Adv 2: 909-922. [Crossref]

46. Nesher L, Shah DP, Ariza-Heredia EJ, Azzi JM, Siddiqui HK, et al. (2016) Utility of the Enzyme-Linked Immunospot Interferon- $\gamma$-Release Assay to Predict the Risk of Cytomegalovirus Infection in Hematopoietic Cell Transplant Recipients. J Infect Dis 213: 1701-1707. [Crossref]

47. El Haddad L, Ariza-Heredia E, Shah DP, Jiang Y, Blanchard T, et al. (2019) The Ability of a Cytomegalovirus ELISPOT Assay to Predict Outcome of Low-Level CMV Reactivation in Hematopoietic Cell Transplant Recipients. J Infect Dis 219: 898-907. [Crossref]

48. Stabile H, Nisti P, Fionda C, Pagliara D, Gaspari S, et al. (2019) NK Cell Reconstitution in Paediatric Leukemic Patients after T-Cell-Depleted HLA-Haploidentical Haematopoietic Stem Cell Transplantation Followed by the Reinfusion of iCasp9Modified Donor T Cells. J Clin Med 8: 1904. [Crossref]

49. Szabolcs P, Niedzwiecki D (2007) Immune reconstitution after unrelated cord blood transplantation. Cytotherapy 9: 111-122. [Crossref]

50. Hill JA, Koo S, Guzman Suarez BB, Ho VT, Cutler C, et al. (2012) Cord-blood hematopoietic stem cell transplant confers an increased risk for human herpesvirus-6associated acute limbic encephalitis: a cohort analysis. Biol Blood Marrow Transplant 18: 1638-1648. [Crossref]

51. Silva LeP, Patah PA, Saliba RM, Szewczyk NA, Gilman L, et al. (2010) Hemorrhagic cystitis after allogeneic hematopoietic stem cell transplants is the complex result of BK virus infection, preparative regimen intensity and donor type. Haematologica 95 : 1183-1190. [Crossref]

52. El Chaer F, Shah DP, Chemaly RF (2016) How I treat resistant cytomegalovirus infection in hematopoietic cell transplantation recipients. Blood 128: 2624-2636. [Crossref]

53. Stabile H, Fionda C, Santoni A, Gismondi A (2018) Impact of bone marrow-derived signals on NK cell development and functional maturation. Cytokine Growth Factor $\operatorname{Rev}$ 42: 13-19. [Crossref]

54. Heslop HE, Ng CY, Li C, Smith CA, Loftin SK, et al. (1996) Long-term restoration of immunity against Epstein-Barr virus infection by adoptive transfer of gene-modified virus-specific T lymphocytes. Nat Med 2: 551-555. [Crossref]
55. Trivedi PP, Roberts PC, Wolf NA, Swanborg RH (2005) NK cells inhibit T cell proliferation via p21-mediated cell cycle arrest. J Immunol 174: 4590-4597. [Crossref]

56. Yu XX, Cao XH, Yan H, Luo XY, Zhao XS, et al. (2019) Delay expression of NKp30 on NK cells correlates with long-term mycophenolate mofetil treatment and higher EBV viremia post allogenic hematological stem cells transplantation. Clin Immunol 2019; 205:49-56. [Crossref]

57. Liu J, Gao H, Xu LP, Mo XD, Liu R, et al. (2020) Immunosuppressant indulges EBV reactivation and related lymphoproliferative disease by inhibiting V 82 . J Immunother Cancer 8: e000208. [Crossref]

58. Saito AM, Kami M, Mori S, Kanda Y, Suzuki R, et al. (2007) Prospective phase II tria to evaluate the complications and kinetics of chimerism induction following allogeneic hematopoietic stem cell transplantation with fludarabine and busulfan. Am J Hematol 82: 873-880. [Crossref]

59. Wang X, Liu J, Gao H, Mo XD, Han T, et al. (2018) Dendritic Cells Are Critical for the Activation and Expansion of V82. Front Immunol 9: 2528. [Crossref]

60. Darlington PJ, Stopnicki B, Touil T, Doucet JS, Fawaz L, et al. (2018) Natural Killer Cells Regulate Th17 Cells After Autologous Hematopoietic Stem Cell Transplantation for Relapsing Remitting Multiple Sclerosis. Front Immunol 9: 834. [Crossref]

61. Josefowicz SZ, Niec RE, Kim HY, Treuting P, Chinen T, et al. (2012) Extrathymically generated regulatory T cells control mucosal TH2 inflammation. Nature 482: 395-399. [Crossref]

62. Trzonkowski P, Bieniaszewska M, Juścińska J, Dobyszuk A, Krzystyniak A, et al (2009) First-in-man clinical results of the treatment of patients with graft versus host disease with human ex vivo expanded $\mathrm{CD} 4+\mathrm{CD} 25+\mathrm{CD} 127-\mathrm{T}$ regulatory cells. Clin Immunol 133: 22-26. [Crossref]

63. Theil A, Tuve S, Oelschlägel U, Maiwald A, Döhler D, et al. (2015) Adoptive transfer of allogeneic regulatory $\mathrm{T}$ cells into patients with chronic graft-versus-host disease. Cytotherapy 17: 473-486. [Crossref]

64. Di Ianni M, Falzetti F, Carotti A, Terenzi A, Castellino F, et al. (2011) Tregs prevent GVHD and promote immune reconstitution in HLA-haploidentical transplantation. Blood 117: 3921-3928. [Crossref]

65. Jaiswal SR, Bhakuni P, Joy A, Murli N, Bharadwaj P, et al. (2018) Impact of SingleDose Plerixafor as an Adjunct to Granulocyte Colony-Stimulating Factor-Based Peripheral Blood Stem Cell Mobilization on the Graft Composition and Outcome for T Cell-Replete Haploidentical Peripheral Blood Stem Cell Transplantation with Post-Transplantation Cyclophosphamide: A Comparative Study. Biol Blood Marrow Transplant 24: 542-548. [Crossref]

66. Roddie C, Peggs KS (2017) Immunotherapy for transplantation-associated vira infections. J Clin Invest 127:2513-22. [Crossref]

67. Walter EA, Greenberg PD, Gilbert MJ, Finch RJ, Watanabe KS, et al. (1995) Reconstitution of cellular immunity against cytomegalovirus in recipients of allogeneic bone marrow by transfer of T-cell clones from the donor. N Engl J Med 333: 10381044. [Crossref]

68. Neuenhahn M, Albrecht J, Odendahl M, Schlott F, Dössinger G, et al. (2017) Transfer of minimally manipulated CMV-specific T cells from stem cell or third-party donors to treat CMV infection after allo-HSCT. Leukemia 31: 2161-2171. [Crossref]

69. Qian C, Campidelli A, Wang Y, Cai H, Venard V, et al. (2017) Curative or pre-emptive adenovirus-specific $\mathrm{T}$ cell transfer from matched unrelated or third party haploidentical donors after HSCT, including UCB transplantations: a successful phase I/II multicenter clinical trial. J Hematol Oncol 10: 102. [Crossref]

70. Kontoyiannis DP, Marr KA, Park BJ, Alexander BD, Anaissie EJ, et al. (2010) Prospective surveillance for invasive fungal infections in hematopoietic stem cell transplant recipients, 2001-2006: overview of the Transplant-Associated Infection Surveillance Network (TRANSNET) Database. Clin Infect Dis 50: 1091-1100. [Crossref]

71. Perruccio K, Tosti A, Burchielli E, Topini F, Ruggeri L, et al. (2005) Transferring functional immune responses to pathogens after haploidentical hematopoietic transplantation. Blood 106: 4397-4406. [Crossref]

72. Audehm S, Krackhardt AM (2017) Specific Adoptive Cellular Immunotherapy in Allogeneic Stem Cell Transplantation. Oncol Res Treat 40: 691-696. [Crossref]

73. Romee R, Cooley S, Berrien-Elliott MM, Westervelt P, Verneris MR, et al. (2018) First-in-human phase 1 clinical study of the IL-15 superagonist complex ALT-803 to treat relapse after transplantation. Blood 131: 2515-2527. [Crossref]

74. Colombetti S, Lévy F, Chapatte L (2009) IL-7 adjuvant treatment enhances long-term tumor-antigen-specific CD8+ T-cell responses after immunization with recombinant lentivector. Blood 113: 6629-6637. [Crossref] 
75. Chaudhry MS, Velardi E, Dudakov JA, van den Brink MR (2016) Thymus: the next (re)generation. Immunol Rev 271: 56-71. [Crossref]

76. Afzali B, Lombardi G, Lechler RI, Lord GM (2007) The role of T helper 17 (Th17) and regulatory $\mathrm{T}$ cells (Treg) in human organ transplantation and autoimmune disease. Clin Exp Immunol 148: 32-46. [Crossref]

77. Long E, Wood KJ (2007) Understanding FOXP3: progress towards achieving transplantation tolerance. Transplantation 84: 459-461. [Crossref]

78. Goriely S, Goldman M (2008) Interleukin-12 family members and the balance between rejection and tolerance. Curr Opin Organ Transplant 13: 4-9. [Crossref]

79. Goriely S, Goldman M (2007) The interleukin-12 family: new players in transplantation immunity? Am J Transplant 7: 278-284. [Crossref]

80. Wood KJ, Sakaguchi S (2003) Regulatory T cells in transplantation tolerance. Nat Rev Immunol 3: 199-210. [Crossref]

81. Ferraris JR, Tambutti ML, Cardoni RL, Prigoshin N (2004) Conversion from cyclosporine A to tacrolimus in pediatric kidney transplant recipients with chronic rejection: changes in the immune responses. Transplantation 77: 532-537. [Crossref]

82. D'Elios MM, Josien R, Manghetti M, Amedei A, de Carli M, et al. (1997) Predominant Th1 cell infiltration in acute rejection episodes of human kidney grafts. Kidney Int 51: 1876-1884. [Crossref]

83. Gras J, Wieërs G, Vaerman JL, Truong DQ, Sokal E, et al. (2007) Early immunological monitoring after pediatric liver transplantation: cytokine immune deviation and graft acceptance in 40 recipients. Liver Transpl 13: 426-433. [Crossref]

84. Segundo DS, Ruiz JC, Izquierdo M, Fernández-Fresnedo G, Gómez-Alamillo $\mathrm{C}$, et al. (2006) Calcineurin inhibitors, but not rapamycin, reduce percentages of $\mathrm{CD} 4+\mathrm{CD} 25+\mathrm{FOXP} 3+$ regulatory $\mathrm{T}$ cells in renal transplant recipients. Transplantation 82: 550-557. [Crossref]

85. Noris M, Casiraghi F, Todeschini M, Cravedi P, Cugini D, et al. (2007) Regulatory $\mathrm{T}$ cells and T cell depletion: role of immunosuppressive drugs. $J$ Am Soc Nephrol 18 1007-1018. [Crossref]

86. Bacchetta R, Gambineri E, Roncarolo MG (2007) Role of regulatory T cells and FOXP3 in human diseases. J Allergy Clin Immunol 120: 227-235. [Crossref]

87. Demirkiran A, Hendrikx TK, Baan CC, van der Laan LJ (2008) Impact of immunosuppressive drugs on $\mathrm{CD} 4+\mathrm{CD} 25+\mathrm{FOXP} 3+$ regulatory $\mathrm{T}$ cells: does in vitro evidence translate to the clinical setting? Transplantation 85: 783-789. [Crossref]

88. Kopf H, de la Rosa GM, Howard OM, Chen X (2007) Rapamycin inhibits differentiation of Th17 cells and promotes generation of FoxP $3+\mathrm{T}$ regulatory cells. Int Immunopharmacol 7: 1819-1824. [Crossref]

89. Hodge S, Hodge G, Flower R, Han P (1999) Methyl-prednisolone up-regulates monocyte interleukin-10 production in stimulated whole blood. Scand J Immunol 49: 548-553. [Crossref]

90. Lionakis MS, Kontoyiannis DP (2003) Glucocorticoids and invasive fungal infections. Lancet 362: 1828-1838. [Crossref]

91. Crespo G, Cervera C, Michelena J, Marco F, Moreno A, et al. (2008) Immune reconstitution syndrome after voriconazole treatment for cryptococcal meningitis in a liver transplant recipient. Liver Transpl 14: 1671-1674.

92. Egli A, Bergamin O, Müllhaupt B, Seebach JD, Mueller NJ, et al. (2008) Cytomegalovirus-associated chorioretinitis after liver transplantation: case report and review of the literature. Transpl Infect Dis 10: 27-43. [Crossref]

93. Place S, Knoop C, Remmelink M, Baldassarre S, Van Vooren JP, et al. (2007) Paradoxical worsening of tuberculosis in a heart-lung transplant recipient. Transpl Infect Dis 9: 219-224. [Crossref]
94. Singh N, Lortholary O, Alexander BD, Gupta KL, Jphn GT, et al. (2005) Allograft loss in renal transplant recipients with cryptococcus neoformans associated immune reconstitution syndrome. Transplantation 80: 1131-1133. [Crossref]

95. Singh N, Lortholary O, Alexander BD, Gupta KL, John GT, et al. (2005) An immune reconstitution syndrome-like illness associated with Cryptococcus neoformans infection in organ transplant recipients. Clin Infect Dis 40: 1756-1761. [Crossref]

96. Lanternier F, Chandesris MO, Poirée S, Bougnoux ME, Mechai F, et al. (2007) Cellulitis revealing a cryptococcosis-related immune reconstitution inflammatory syndrome in a renal allograft recipient. Am J Transplant 7: 2826-2828. [Crossref]

97. Vlasova-St Louis I, Chang CC, Shahid S, French MA, Bohjanen PR (2018) Transcriptomic Predictors of Paradoxical Cryptococcosis-Associated Immune Reconstitution Inflammatory Syndrome. Open Forum Infect Dis 5: ofy157. [Crossref]

98. Husain S, Wagener MM, Singh N (2001) Cryptococcus neoformans infection in organ transplant recipients: variables influencing clinical characteristics and outcome. Emerg Infect Dis 7: 375-381.

99. Co DO, Hogan LH, Il-Kim S, Sandor M (2004) T cell contributions to the different phases of granuloma formation. Immunol Lett 92: 135-142.

100. HR, Zhao Z, Rosborough BR, Liu Q, Castellaneta A, et al. (2011) IL-33 expand suppressive $\mathrm{CD} 11 \mathrm{~b}+\mathrm{Gr}-1$ (int) and regulatory T cells, including ST2L+Foxp3+ cells, and mediates regulatory $\mathrm{T}$ cell-dependent promotion of cardiac allograft survival. $J$ Immunol 187: 4598-4610. [Crossref]

101. Reichenbach DK, Schwarze V, Matta BM, Tkachev V, Lieberknecht E, et al. (2015) The IL-33/ST2 axis augments effector T-cell responses during acute GVHD. Blood 125: 3183-3192. [Crossref]

102. Liew FY, Girard JP, Turnquist HR (2016) Interleukin-33 in health and disease. Nat Rev Immunol 16: 676-689. [Crossref]

103. Matta BM, Reichenbach DK, Zhang X, Mathews L, Koehn BH, et al. (2016) PerialloHCT IL-33 administration expands recipient T-regulatory cells that protect mice against acute GVHD. Blood 128: 427-439. [Crossref]

104. Cayrol C, Girard JP. IL-33: an alarmin cytokine with crucial roles in innate immunity, inflammation and allergy. Curr Opin Immunol 2014; 31:31-7. [Crossref]

105. Libby P (2002) Inflammation in atherosclerosis. Nature 420: 868-874. [Crossref]

06. Einecke G, Sis B, Reeve J, Mengel M, Campbell PM, et al. (2009) Antibodymediated microcirculation injury is the major cause of late kidney transplant failure. Am J Transplant 9: 2520-2531. [Crossref]

107. Mitchell RN, Libby P (2007) Vascular remodeling in transplant vasculopathy. Circ Res 100: 967-978.

108. Strom TB, Roy-Chaudhury P, Manfro R, Zheng XX, Nickerson PW, et al. (1996) The Th1/Th2 paradigm and the allograft response. Curr Opin Immunol 8: 688-693. [Crossref]

109. Tay SS, Plain KM, Bishop GA (2009) Role of IL-4 and Th2 responses in allograft rejection and tolerance. Curr Opin Organ Transplant 14: 16-22. [Crossref]

110. Nickerson P, Steurer W, Steiger J, Zheng X, Steele AW, et al. (1994) Cytokines and the Th1/Th2 paradigm in transplantation. Curr Opin Immunol 6: 757-764.

111. Dallman MJ (1995) Cytokines and transplantation: Th1/Th2 regulation of the immune response to solid organ transplants in the adult. Curr Opin Immunol 7: 632 638. [Crossref]

112. Braun MY, Desalle F, Le Moine A, et al. (2000) IL-5 and eosinophils mediate the rejection of fully histoincompatible vascularized cardiac allografts: regulatory role of alloreactive CD8(+) T lymphocytes and IFN-gamma. Eur J Immunol 30: 1290-1296. [Crossref]

Copyright: (C2020 Kellampalli U. This is an open-access article distributed under the terms of the Creative Commons Attribution License, which permits unrestricted use, distribution, and reproduction in any medium, provided the original author and source are credited. 